\title{
Pengaruh Diabetes Mellitus Gestasional Terhadap Sirkulasi Uteroplasenta
}

\section{The Effects Of Gestational Diabetes Mellitus To Uteroplasental Circulation}

\author{
Isngadi*, Redhy Sindharta ${ }^{*}$, Yusmein Uyun*, Sri Rahardjo** \\ * Bagian Anestesi dan Terapi Intensif Fakultas Kedokteran Universitas Barwijaya/ RSUD dr. Saiful Anwar Malang \\ ** Bagian Anestesiologi dan Terapi Intensif FK UGM/ RSUP dr. Sardjito, Yogyakarta \\ $\triangle$ Korespondensi/ Correspondence: redhysindharta@gmail.com
}

\begin{abstract}
Diabetes mellitus in pregnancy (Gestational Diabetes Mellitus/ GDM) is defined as glucose intolerance found first time in pregnancy and frequently induce complication to the mother and fetus. In GDM, some organs undergo structural and functional changes including microcirculation endothelial dysfunction and fetoplacental macrocirculation dysfunction.
\end{abstract}

Endothelium-derived Relaxing Factors (EDRF) especially prostacyclin and nitric oxide play important roles in controlling fetoplacental circulation. Vascular endothelial dysfunction in GDM leads to dysfunction in the synthesis and release of prostacyclin and nitric oxide (NO), consequently increasing arterial tonus. The increase of arterial tonus decreases uteroplasental blood flow and then decreases umbilical blood flow (UmBF). Vascular endothelial is the main target of oxidative stress. NO synthesis is an important mechanism which regulates systemic vascular and uterine vascular changes in pregnancy.

Evidences from studies support the roles of NO and ADMA in normal pregnancy and placental insufficiency. With the increasing knowledge in ADMA-NO pathway dysfunction mechanism, there will be alternative choices of therapeutic intervention. General managements of GDM are diet control, physical exercise if no contraindication, blood glucose monitor and control, and pharmacological therapy. Other studies continue to find new therapies to improve endothelial and uteroplacental circulation in GDM.

Key Words: Diabetes mellitus, gestational, endothelial, uteroplacenta, circulation

\section{ABSTRAK}

Diabetes mellitus pada kehamilan (Gestational diabetes mellitus/GDM) adalah intoleransi glukosa yang ditemukan pertama kali pada masa kehamilan dan sering menimbulkan komplikasi pada ibu yang mengandung maupun janin yang dikandung. Beberapa organ pada GDM mengalami perubahan struktur dan perubahan fungsi 
termasuk disfungsi endothel mikrosirkulasi dan makrosirkulasi fetoplasenta.

Endothelium-derived Relaxing Factors (EDRF) khususnya prostasiklin dan nitrik oksid berperan penting dalam mengontrol sirkulasi fetoplasental. Endothel vaskuler pasien GDM mengalami disfungsi, sehingga sintesa dan pelepasan prostasiklin dan nitrik oksid (NO) mengalami gangguan sehingga tonus arteria meningkat. Peningkatan tonus arteri yang menuju uterus akan menurunkan aliran darah uteroplasenta dan akhirnya menurunkan umbilical blood flow (UmBF). Endothel pembuluh darah merupakan target utama dari stress oksidatif. Sintesa NO merupakan mekanisme penting yang mendasari perubahan pembuluh darah sistemik dan pembuluh darah uterine selama kehamilan.

Beberapa evidensi penelitian membuktikan peranan NO dan ADMA pada kehamilan normal dan insufiensi plasenta. Dengan berkembangnya pengetahuan akan mekanisme gangguan jalur ADMA-NO, pilihan tambahan untuk intervensi terapetik akan dapat ditemukan. Tatalaksana GDM secara umum adalah dengan pengaturan diet, latihan fisik selama tidak ada kontraindikasi, pengawasan dan kontrol gula darah, dan terapi farmakologi Berbagai penelitian lain terus berusaha menemukan terapi-terapi baru untuk memperbaiki endothel dan sirkulasi uteroplasenta pada pasien GDM.

Kata Kunci: Diabetes mellitus, gestasional, endothel, sirkulasi uteroplasenta

\section{PENDAHULUAN}

Diabetes mellitus merupakan penyakit metabolik yang ditandai adanya hiperglikemia akibat gangguan sekresi insulin dan atau gangguan fungsi insulin. ${ }^{1}$ Diabetes mellitus pada kehamilan (Gestational diabetes mellitus /GDM) adalah intoleransi glukosa yang ditemukan pertama kali pada masa kehamilan ${ }^{2}$. Insidensi Diabetes mellitus pada seluruh kehamilan sekitar 4,5\%. Prevalensi GDM di Amerika sekitar 1\% - 25\% tergantung demografi pasien dan waktu dimulainya tindakan diagnostic. ${ }^{2}$

\begin{tabular}{llr}
\multicolumn{1}{c}{ Diabetes } & mellitus & pada masa \\
kehamilan & sering & menimbulkan \\
komplikasi pada ibu yang & mengandung, \\
maupun janin yang dikandung.
\end{tabular}

Komplikasi tersebut dapat berupa preeklamsia, fetal makrosomia dan neonatal hipoglikemia. ${ }^{2}$ Manifestasi klinis dari GDM berkaitkan dengan kondisi hiperglikemia, hiperlipidemia, hiperinsulinemia dan disfungsi endothel fetoplasenta. Pada GDM, beberapa organ menunjukkan perubahan struktur dan perubahan fungsi termasuk disfungsi endothel mikro dan makrosirkulasi fetoplasenta ${ }^{3}$. Ibu dengan hiperglikemia dapat mempengaruhi aliran darah ke janin kemungkinan diperantarai oleh mediator pembuluh darah. Endothelium-derived relaxing faktor khususnya prostasiklin dan nitrit oksida merupakan hal yang penting dalam mengontrol sirkulasi fetoplasental. ${ }^{4}$ 
Disfungsi endothel berperan penting terhadap pathogenesis dan ekpresi klinis pada pasien diabetes mellitus ${ }^{5}$. Endothel yang mengalami disfungsi akan berakibat vasokonstriktor tidak ada yang menetralisasi sehingga tonus arteri meningkat. ${ }^{5,6}$

Dalam keadaan hamil, pembuluh darah ke uterus mengalami dilatasi maksimal, akan tetapi pada diabetes mellitus gestasional terjadi disfungsi endothel yang menyebabkan penurunan aliran darah ke uterus sebagai akibat dari peningkatan tonus arteri yang menuju uterus. Sirkulasi uteroplasenta merupakan sirkulasi yang bertanggung jawab untuk pengiriman nutrisi dan oksigen ke fetus. Sirkulasi uteroplasenta yang normal merupakan hal yang sangat penting untuk pertumbuhan janin yang sehat. Penurunan aliran darah uteroplasenta secara akut dapat berakibat mengancam kelangsungan hidup janin secara tiba-tiba, sedangkan penurunan aliran uteroplasenta yang kronik dapat menyebabkan proses patologis kehamilan seperti preeklamsia dan hambatan pertumbuhan janin. ${ }^{4,7}$ Komplikasi yang terjadi akibat diabetes mellitus pada kehamilan dapat dicegah dengan cara deteksi awal dan segera memberikan penanganan. Melakukan kontrol hiperglikemi merupakan cara terbaik untuk memperbaiki fungsi endothel dan mencegah komplikasi kardiovaskuler sehingga dapat memperbaiki outcome baik pada ibu maupun bayinya. ${ }^{6,9,10}$

\section{TINJAUAN PUSTAKA}

\section{Diagnosis Diabetes Mellitus \\ Gestasional (GDM)}

Diabetes mellitus (DM) merupakan penyakit metabolik yang ditandai oleh hiperglikemia sebagai akibat dari gangguan sekresi insulin, gangguan aksi insulin atau gangguan keduanya $^{1}$. Diangnosis diabetes mellitus ditegakan apabila ditemukan kadar gula darah puasa $\geq 126 \mathrm{mg} / \mathrm{dl}$ dan kadar gula darah 2 jam post pandrial $\geq$ $200 \mathrm{mg} / \mathrm{dl}$. Prevalensi DM pada populasi dewasa di Amerika sebesar 6,8 $\% \quad$ sampai $8,2 \%$, sedangkan prevalensinya DM pada kehamilan adalah sebesar $1 \%-25 \% .^{2,5}$

$$
\text { Diabetes mellitus pada }
$$
kehamilan (GDM) merupakan glukosa intoleran yang terdiagnosa pertama kali selama kehamilan. Kriteria diagnosis DM pada kehamilan ditegakkan berdasarkan peremeriksaan oral glucose tolerance test (OGTT), dengan cara mengukur kadar glukosa pada saat puasa, 1 jam dan 2 jam setelah pemberian glukosa 75 gram. Glukosa 75 gram tersebut diberikan pada pagi hari yang sebelumnya pasien dipuasakan 8 jam. Diagnosis GDM ditegakkan apabila ditemukan salah satu dari hasil berikut, 1). Kadar gula dalam plasma saat puasa $\geq 92 \mathrm{mg} / \mathrm{dl}$, 2).Kadar gula dalam plasma setelah 1 
jam pemberian glukosa $75 \mathrm{gr} \geq 180 \mathrm{mg} /$ dl, 3). Kadar gula dalam plasma setelah 2 jam pemberian glukosa $75 \mathrm{gr} \geq 153$ $\mathrm{mg} / \mathrm{dl}$. $^{1,2}$

\section{Aliran Darah Uteroplasenta}

Aliran darah uteropasenta (uteroplacental blood flow /UPBF) yang normal sangat penting dalam perkembangan dan pemeliharaan janin yang sehat (Gambar 1 dan gambar 2). Insufisiensi aliran uteroplasenta merupakan penyebab penting terjadinya hambatan pertumbuhan janin intra uterin, dan jika insufisiensi aliran uteroplasenta terjadi secara parah maka dapat menyebabkan kematian janin. Sirkulasi uteroplasenta ini sangat tergantung pada dua hal yaitu : aliran darah ke uterus yang adekuat dan fungsi plasenta yang normal ${ }^{7}$. Sedangkan UBF dirumuskan sebagai berikut :

$\mathrm{UBF}=(\mathrm{UAP}-\mathrm{UVP}) / \mathrm{UVR}$

$\mathrm{UBF}=$ uterine blood flow

$\mathrm{UVP}=$ uterine venous pressure

$\mathrm{UAP}=$ uterine arterial pressure

$\mathrm{UVR}=$ uterine vascular resistance

Dengan demikian semua keadaan yang menurunkan tekanan darah rata-rata ibu atau meningkatkan resistensi vaskuler uterus akan menurunkan UPBF dan akhirnya menurunkan umbilical blood flow $(\mathrm{UmBF}) .{ }^{4,12}$
Aliran darah ke uterus tidak hamil sekitar $50 \mathrm{ml} /$ menit, sedangkan pada uterus hamil merupakan $10 \%$ dari cardiac output atau sekitar 600-700 $\mathrm{ml} / \mathrm{menit}, 80 \%$ dari aliran darah ke uterus ini masuk ke plasenta sedangkan sisanya mengalir ke myometrium. Dalam keadaan hamil, pembuluh darah ke uterus mengalami maksimal dilatasi oleh karena itu tidak ada fungsi atoregulasi, akan tetapi pembuluh darah ke uterus ini sangat sensitif terhadap agonis reseptor $\alpha_{1 .}^{4,7,8}$

Sumber utama aliran darah ke uterus adalah dari dua arteri uterine, sedangkan pasokan dari arteri ovarika sangat bervariasi tergantung dari spesiesnya. Kompleksnya pasokan arteri ini menyebabkan pengukuran langsung UBF sangat sulit terutama pada manusia. Pada kebanyakan kasus kecukupan perfusi plasenta dapat diperkirakan secara tidak langsung dengan monitoring denyut jantung janin dan keadaan asam - basa. ${ }^{4}$

Penurunan aliran darah ke uterus dapat disebabkan oleh penurunan tekanan darah sistemik, vasokonstriksi pembuluh darah uterina, kontraksi uterus. Penyebab hipotensi yang sering terjadi pada kehamilan adalah aortocaval compression, hipovolemi, dan blokade simpatis akibat tindakan anestesi regional. Stres selama proses persalinan menginduksi pelepasan katekolamin endogen yang berdampak vasokonstriksi arteri uterine. Obat-obat yang mempunyai 
aktivitas terhadap reseptor adrenergik $\alpha$ misalnya fenileprin berpotensi menurunkan aliran darah ke uterus melalui vasokonstriksi pembuluh darah uterus. Ephedrin merupakan obat yang bekerja juga pada reseptor adrenergic- $\beta$ sehingga dipertimbangkan sebagai obat pilihan untuk mengatasi hipotensi pada kehamilan. ${ }^{7,8}$

Penyakit hipertensi juga dapat menyebabkan aliran darah uterus menurun melalui mekanisme vasokonstriksi umum. Kontraksi uterus menurunkan aliran darah ke uterus karena terjadi peningkatan tekanan darah vena uterina dan terjadi penekanan pembuluh darah arteri uterine. Konstraksi hipertonik uterus dan pemberian infuse oksitosin selama proses persalinan berisiko terjadi kondisi kritis terhadap aliran darah ke uterus. $^{7,8}$

\section{Regulasi Aliran Darah Uteroplasenta Selama Kehamilan}

Perubahan pembuluh darah selama kehamilan belum diketahui secara pasti, akan tetapi ada beberapa faktor yang dianggap berpengaruh terhadap perubahan vaskuler selama kehamilan antara lain: hormon steroid, penurunan respon terhadap vasokonstriktor, endothelium derived vasodilator, peningkatan shear stress, dan perubahan venoarterial ${ }^{4}$.

Steroid berperan dalam regulasi sirkulasi uteroplasenta. Estrogen mempunyai peran penting dalam mengatur perubahan pembuluh darah uterine pada kehamilan. Pemberian estrogen eksogen menyebabkan vasodilatasi pembuluh darah uterine dan meningkatkan aliran darah uterus. Efek vasodilatasi tersebut diperantarai melalui reseptor ER- $\alpha$ dan ER- $\beta$. Selain itu juga terdapat membrane reseptor yang memperantarai up regulating produksi NO melalui aktivasi dari endothelial nitric oxide synthase (eNOS). ${ }^{4} \quad$ Progresteron memodulasi efek estrogen pada pembuluh darah uterus. Pemberian progesteron saja pada wanita tidak hamil, tidak terjadi vasodilatasi pada vaskuler uterine, tetapi mempunyai efek inhibisi jika diberikan bersama estrogen. Progesteron menyebabkan down regulation, terhadap ekpresi estrogen reseptor. Peningkatan rasio estrogen-progesteron pada akhir kehamilan sejajar dengan peningkatan UBF. Kortisol mempunyai efek lokal maupun efek sistemik terhadap aliran darah ke uterus. Secara sistemik, kortisol mengatur aliran darah uterus dengan cara meningkatkan volume plasma. Kortisol dipercaya menurunkan ekpresi eNOS dan menurunkan pelepasan NO, hal ini akan berpotensiasi dengan respon vasokonstriktor seperti angiotensin II, vasopressin dan norepinephrine. ${ }^{4}$

Pada keadaan hamil respon terhadap vasokonstriktor termasuk angiotensin II, endotelin, tromboksan, epineprin, norepineprin, penileprin, serotonin, arginine dan vasopressin 


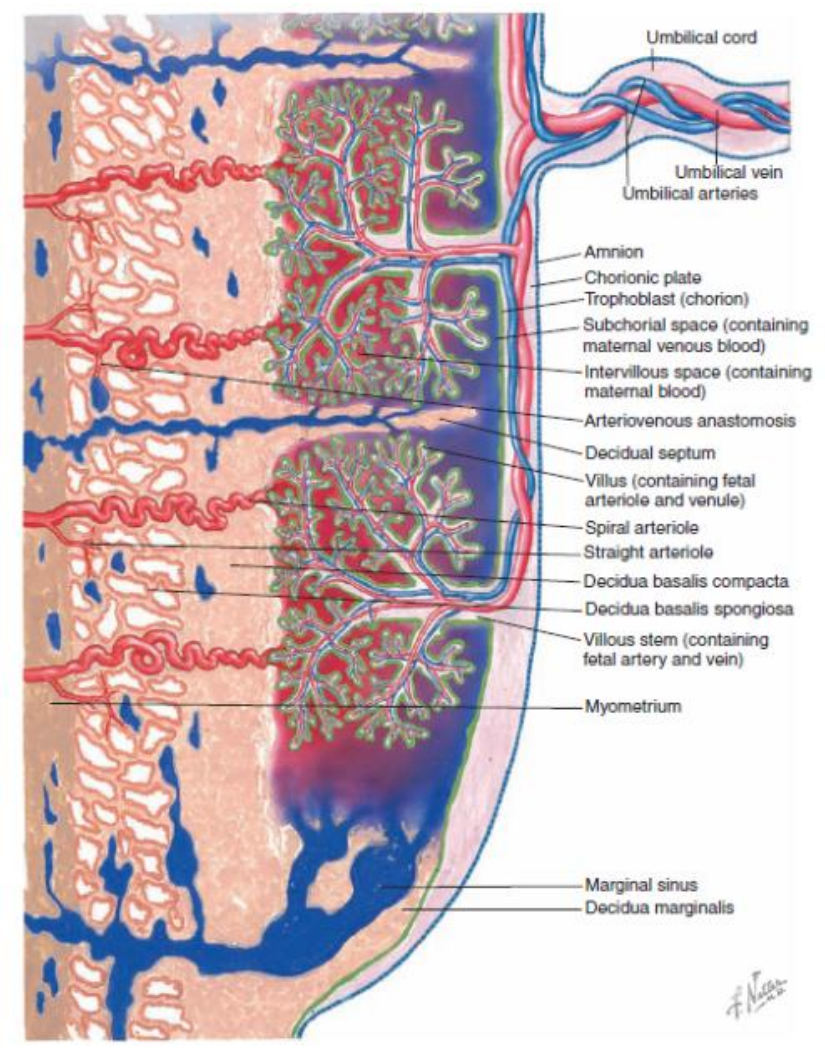

Gambar 1. Sirkulasi Plasenta. ${ }^{7,8}$

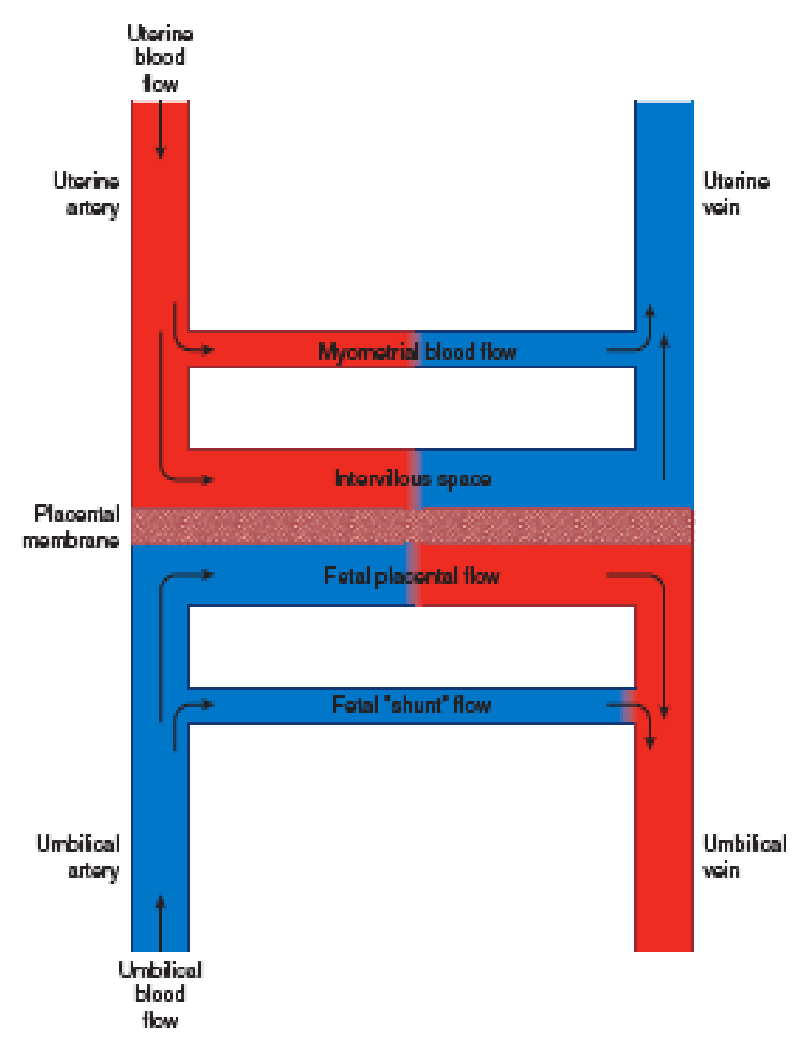

Gambar 2. Sirkulasi uteroplasental. ${ }^{7,8}$

$E C$

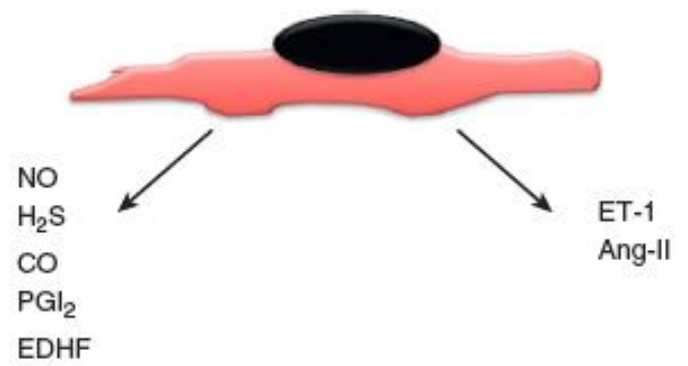

\begin{tabular}{|l|}
\hline sGC/cGMP \\
AC/cAMP \\
$\mathrm{K}+$ channels \\
\hline
\end{tabular}

VSMC

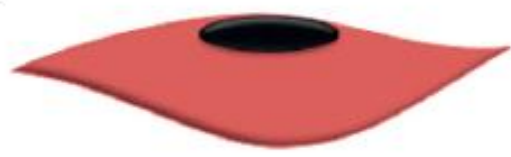

Vasodilation

Vasoconstriction

Gambar 3.Endothelium derived vasoactive factors. ${ }^{12}$ 
mengalami penurunan. Pada saat hamil, konsentrasi angiotensin II dalam darah ibu meningkat dua sampai tiga kali, akan tetapi respon terhadap terhadap angiotensin menurun. Penurunan respon terhadap vasopressor ini berkurang pada pasien preeklamsia. Respon terhadap angiotensin II pada sirkulasi uterus lebih rendah daripada repon angiotensin II dalam sirkulasi sistemik. Hal ini terjadi karena adanya perbedaan subtipe reseptor angiotensin II. Pada pembuluh darah sistemik reseptor AT1R dominan dan memperantarai terjadinya vasokonstriksi, sedangkan pada arteri uterine dan myometrium didominasi reseptor AT2R yang tidak menyebabkan kontraksi otot polos. ${ }^{4}$

Sintesis dan kadar dalam sirkulasi dari Endothelium derived vasodilator pada masa hamil mengalami peningkatan. Produksi prostasiklin pada pembuluh darah uterus lebih besar daripada produksinya pada pembuluh darah sistemik. Hal ini mungkin berguna untuk mempertahankan aliran darah ke uterus untuk melawan efek vasokonstriktor dalam sirkulasi. Nitrik Oksid yang disintesis dari arginine di dalam endothel pembuluh darah yang selanjutnya memacu soluble guanylate cyclase dalam otot polos vaskuler yang menghasilkan vasodilatasi melalui peningkatan cyclic guanosine monophosphate (cGMP). Sintesa NO merupakan mekanisme penting yang mendasari perubahan pembuluh darah sistemik dan pembuluh darah uterine selama kehamilan. Hambatan yang lama terhadap sintesa NO dapat menyebabkan hipertensi dan gangguan pertumbuhan janin. ${ }^{4}$

\section{Endothel Pembuluh Darah.}

Pada tahun 1983 ahli fisiologi german (Theodor Schwann) orang pertama yang menjelaskan "membrane tipis" yang merupakan bagian dari pembuluh darah kapiler yang membatasi sirkulasi darah dari jaringan. Membran selapis sel ini akhir-akhir ini disebut dengan endothelium. ${ }^{11}$ Awalnya endothel diyakini sebagai penampung pasif untuk sirkulasi darah, sel dan makromolekul. Sekarang endothel diketahui sebagai struktur seluler dinamis yang mempunyai sifat biologis dan fungsional yang luas. Sebagai struktur sel yang berada di permukaan lumen pembuluh darah, endothel selalu kontak dengan aliran darah, endothel berperan sebagai tromboresisten, membran semi permeabel, mengatur interaksi dengan sirkulasi sel inflamasi, dan imunitas seluler. Sebagai respon terhadap pulsasi dan tekanan aliran darah, endothel juga melepaskan subtansi vasoaktif yang meregulasi tonus vaskuler. $^{12}$

Fungsi Endothel pada Sistem Sirkulasi.

Endothel pembuluh darah tidak sekedar selapis sel yang melapisi permukaan pembuluh darah, tetapi endothel merupakan organ yang 
komplek dan terdapat kelenjar parakrin maupun autokrin yang merupakan lini pertama untuk melawan terjadinya atheroskerosis. ${ }^{6,10}$ Ada 4 peran utama dari endothel yaitu: meregulasi vasodilatasi maupun vasokontrisi dari pembuluh darah, mempertahankan fluiditas darah, mempertahankan integritas pembuluh darah dan mencegah perdarahan, berperan dalam proinflamasi atau antiinflamasi mengatur pertumbuhan atau perubahan fenotif dari otot polos pembuluh darah. ${ }^{6}$

Endotel adalah lapisan sel yang melapisi dinding vaskular yang menghadap ke lumen dan melekat pada jaringan subendotel yang terdiri atas kolagen dan berbagai glikosaminoglikan termasuk fibronektin. ${ }^{14,15}$ Dahulu dianggap bahwa fungsi endotel adalah sebagai barrier struktural antara sirkulasi dengan jaringan di sekitarnya, tetapi sekarang telah diketahui bahwa endotel berfungsi mengatur tonus vaskular, mencegah trombosis, mengatur aktivitas sistem fibrinolisis, mencegah perlekatan leukosit dan mengatur pertumbuhan vascular. ${ }^{16,17}$ Substansi vasoaktif yang dikeluarkan endotel antara lain nitric oxide (NO) yang juga disebut endothelial-derived relaxing factor (EDRF), endothelial-derived hyperpolarizing factor (EDHF), prostasiklin (PGI2), bradikinin, asetilkolin, serotonin dan histamine. Substansi vasokonstriktor antara lain endothelin, platelet activating factor
(PAF), angiotensin II, prostaglandin $\mathrm{H} 2$, trombin dan nikotin. ${ }^{2,13,14,17}$ (Gambar 3). Endotel juga berperan pada hemostasis dengan mempertahankan permukaan yang bersifat antitrombotik. Melalui ekspresi trombomodulin, endotel membantu trombin dalam mengaktifkan protein $\mathrm{C}$ menjadi protein $\mathrm{C}$ aktif. Selain itu endotel juga mensintesis protein $\mathrm{S}$ yang bekerja sebagai kofaktor protein $\mathrm{C}$ dalam menginaktivasi faktor $\mathrm{Va}$ dan factor VIIIa. Endotel juga mensintesis factor von Willebrand (vWF) yang berfungsi dalam proses adhesi trombosit dan sebagai pembawa factor VIII. Faktor von Willerand disimpan di dalam Weibel-Palade bodies. Sekresi vWF dapat terjadi melalui 2 mekanisme yaitu secara konstitutif dan secara inducible.

Peran endothel dalam mengatur tonus pembuluh darah sangat tergantung pada produksi endothelialderived relaxing factor (EDRF) danendothelial-derivedcontracting factors (EDCF). Dalam keadaaan normal terdapat keseimbangan antara produksi endothelial-derived relaxing factor danendothelial-derived contracting factors sehingga terdapat keseimbangan antara kontraksi dan relaksasi dari pembuluh darah., ${ }^{2,5}$ Endothelium memproduksi molekul vasodilator berupa nitric oksid (NO) dan Edothelium derived hyperpolarizing factor (EDHF). Selain itu endotheium juga memproduksi 
vasokontriktor termasuk endothelin-1 (ET-1), prostaglandin dan angiotensin II.

Nitrik oksid (NO) endogen diproduksi melalui konversi dari asam amino 1-arginin menjadi 1-citrulline oleh enzim NO-synthase (NOS) tipe III yang sering juga disebut sebagai constitutive-NOS. NO yang diproduksi oleh constitutive-NOS di endothelium akan menyebar ke otot polos pembuluh darah yang selanjutnya mengaktivasi enzim Guanilat siklase. Aktivasi enzim guanilat siklase ini selanjutnya meningkatkan kadar siklik GMP yang akan menginduksi terjadinya relaksasi pembuluh darah. ${ }^{6,13}$ Angiotensin II diproduksi oleh endothelium jaringan pembuluh darah lokal yang berperan sebagai regulator pada otot polos pembuluh darah berupa : vasokontriksi, pertumbuhan, proliferasi dan diferensiasi dari otot polos pembuluh darah. NOS juga diatur oleh kadar lokal dari bradikinin. Peptida ini bekerja melalui reseptor $\beta 2$ pada permukaan membran sel endothelium selanjutnya mengaktivasi NOS yang akan meningkatkan produksi NO. Sedangkan konsentrasi bradikinin diregulasi oleh aktivitas angiotensin converting enzyme (ACE). Peran ACE dalam meregulasi bradikinin adalah dengan merusak bradikinin menjadi peptide inaktif . ${ }^{6}$

Produksi vasodilator oleh endothel distimuli oleh beberapa faktor seperti: asetilkholin, thrombin, serotonin, angiotensin II, dan agonist adrenergik alpha (Gambar 4.). Faktorfaktor tersebut juga mempunyai efek langsung vasokonstriksi, NO dan vasodilator lain yang diproduksi endothelium melawan efek vasokonstriktor faktor-faktor tersebut, aksi ini merupakan homeostasis yang mempertahankan patensi arteri secara normal. Stimulus lain yang memacu produksi NO dari endothelium adalah peningkatan shear stress. Shear stress merupakan gaya gesekan pada permukaan endothel vaskuler yang terjadi karena adanya aliran darah. Shear stress berhubungan langsung dengan besarnya aliran arteri dan berbanding terbalik dengan diameter arteri. Pada saluran pembuluh arteri yang normal, jika terjadi peningkatan aliran darah, maka akan merangsang terjadinya flow-mediated dilation yang selanjutnya menyebabkan peningkatan diameter dari arteri yang bersangkutan. ${ }^{5}$

Peran endothel dalam mempertahankan fluiditas darah , integritas pembuluh darah dan mencegah perdarahan melalui keseimbangan antara sistim koagulasi dan system fibrinolysis. Sedang peran endothelium dalam pertumbuhan dan deferensiasi otot polos pembuluh darah diperantari melalui pelepasan promoters of growth dan atau inhibitor of growtyang selanjutnya mempengaruhi remodeling vaskuler. Perkembangan dari pertumbuhan otot polos pembuluh darah diperantarai oleh platelet growth factor (PGF) dan 


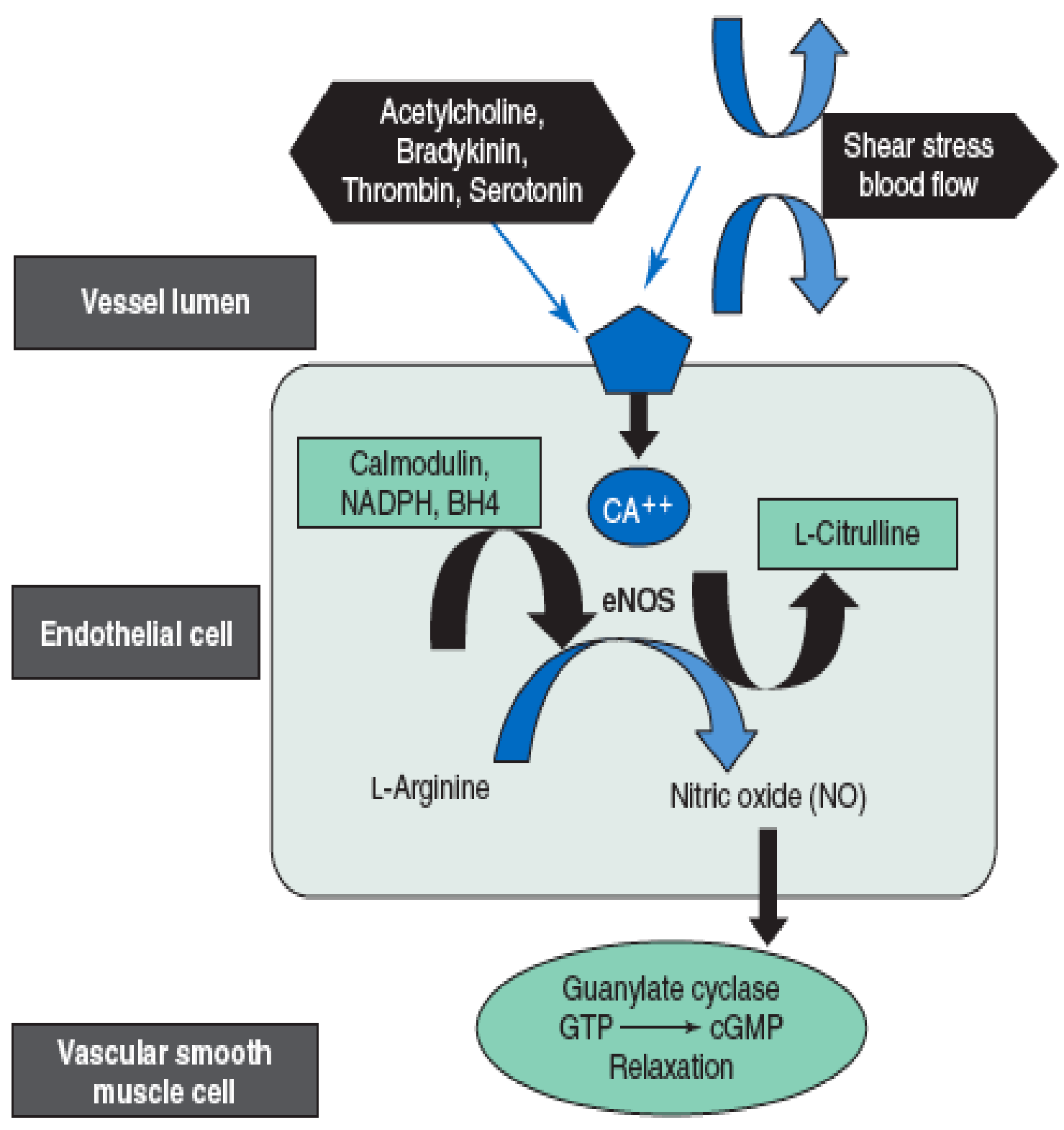

Gambar 4. Sintesa dan pelepasan $\mathrm{NO}^{20}$ 
ANG-II yang diproduksi lokal. Endothel juga berperan memproduksi molekul spesifik yang mempunyai peran penting dalam proses inflamasi misalnya: leukocyte adhesion molecule (LAM), intracellular adhesion molecule (ICAM) dan vascular cell adhesion molecule (VCAM). Molekulmolekul ini disebut sebagai molekul adesi (adhesion molecules) dan berfungsi menarik dan menempelkan pada sel-sel yang terlibat reaksi inflamasi. ${ }^{6}$ Proses atherosklerosis berhubungan dengan peningkatan kadar pertanda peradangan (protein fase akut) dalam darah. Endotel juga berperan dalam sistem fibrinolisis melalui pelepasan tissue plasminogen activator (tPA) yang akan mengaktifkan plasminogen menjadi plasmin. Namun endotel juga mensintesis plasminogen activator inhibitor-1(PAI-1) yang berfungsi menghambat tPA.

\section{Perubahan Endothel pada Diabetes Mellitus.}

Disfungsi endothel merupakan ketidakmampuan endothel pembuluh darah untuk mempertahankan homeostasis vaskuler, ketidakmampuan ini berkaitan dengan penurunan kadar nitrik oksid (NO) dalam pembuluh darah, peningkatan vasokontriktor, gangguan regulasi inflamasi, thrombosis, dan pertumbuhan sel pada dinding pembuluh darah., ${ }^{5,6}$ Telah diketahui ada hubungan antara disfungsi endothel dengan resistensi terhadap insulin seperti pada pasien DM dan obesitas. Endothel yang mengalami disfungsi akan berakibat vasokontriktor tidak ada yang menetralisasi sehingga tonus arteria meningkat. Kondisi disfungsi endothelium ini akan menyebabkan peningkatan produksi endothelin-1 dan endothelium-derived-vasocontrictor yang lain yang selanjutnya akan mempengaruhi vasospasme dan peningkatan kekakuan arteri. ${ }^{5,6}$

Perubahan signaling sel pada jalur aktivasi eNOS di endothel merupakan mekanisme penting terjadinya disfungsi endothel pada DM. Produksi NO di endothelium tergantung pada proses enzimatik oleh eNOS yang mengubah L arginine menjadi NO dan citrullin. Enzim ini dikeluarkan dari sel endothelium yang terletak dalam kaveola. Kaveola ini berinvaginasi dari dalam membrane plasma yang kaya protein dan lemak spesifik termasuk caveolin-1. Dalam keadaan aktifitas basal, kadar eNOS rendah pada karena berhubungan dengan caveolin-1, tetapi kadar eNOS ini dapat diaktivasi misalnya dengan agonist reseptor asetilkholin dan serotonin yang akan meningkatkan calcium intrasel dan akan memulai perubahan calcium calmodulin pada caveolin -1 selanjutnya mengaktivasi enzim tersebuteNOS dapat diaktivasi juga oleh heat shock protein, bradikinin, estrogen dan shear stress melalui aktivasi phosphoinositide-3 kinase (PI3kinase)/ sistem Akt. Insulin juga merupakan stimulus terhadap aktivasi eNOS. Ikatan insulin pada reseptornya 
di endothel akan memulai terjadinya phosphorilasi dari insulin reseptor substrate-1 (IRS-1) yang selanjutnya terjadi phosphorilasi dan aktivasi dari eNOS melalui PI3 kinase /Akt. Adanya mutasi pada IRS-1 menurunkan phosphorilasi eNOS dan ekpresi gen pada kultur endothel yang dipapar insulin. ${ }^{5}$

Insulin juga mengaktifkan mitogen-activated protein kinases (MAPK) melalui GTPase Ras. Signal insulin melalui jalur MAPK akan memulai pertubuhan dan proliferasi sel. Aktivasi melalui jalur tersebut pada endothel berhubungan dengan ekspresi dari endothelin-1, yang merupakan vasokonstriktor kuat, mitogen, dan untuk ekpresi proinflamasi molekul adhesi seperti ICAM-1. Pada DM dan resistensi insulin aktivasi eNOS yang diperantarai insulin melalui PIP3 kinase mengalami penghambatan,aliran darah dan stimuli fisiologis lain untuk mengaktivasi eNOS melalui PIP3 juga mengalami perusakan. Selain itu pada DM juga terjadi peningkatan caveolin-1 endothel dan jaringan lemak, terjadi hambatan interaksi antara eNOS dan heat shock protein 90, dan terdapat peningkatan kadar inhibitor eNOS endogen yang semuanya akan mengganggu produksi NO. ${ }^{5}$ Jadi kerusakan fungsi endothelium pada DM bersifat multifaktor meliputi gangguan signaling sel, gangguan aktivitas enzim yang selanjutnya dapat mengurangi kemampuan endothel untuk memproduksi NO.
Hiperglikemia merupakan faktor utama penyebab terjadinya disfungsi endothel pada DM walaupun faktor penyebab terjadinya disfungsi endothel adalah multifactor. ${ }^{6}$ Resistensi terhadap insulin telah diketahui pada beberapa penyakit yang meningkatkan resiko terjadinya penyakit dan meningkatkan resiko kematian penyakit kardiovaskuler. Penyakit tersebut antara lain: DM, obesitas, hipertensi dan metabolik. Telah terbukti bahwa perkembangan resisten terhadap insulin pada DM tipe 2 berhubungan dengan peningkatan disfungsi endothel. Resistensi insulin berhubungan erat dengan jaringan lemak visceral dan asam lemak bebaslah yang bertanggungjawab dalam hubungan ini. Biomarker plasma lainnya yang dihasilkan oleh jaringan lemak adalah TNF dan resitin yang terbukti meningkat pada obesitas dan memperantarai terjadinya resistensi insulin. Sebaliknya, ekspresi dan sekresi adiponektin dan jaringan protein spesifik yang meningkatkan penyerapan glukosa diperantarai insulin berkorelasi terbalik dengan massa lemak. Pada pasien dengan DM tipe 2 telah diketahui terjadi peningkatan metabolism dari NO atau mengalami respon yang abnormal otot polos pembuluh darah karena terjadi perubahan sinyal transduksi pada jalur guanilat siklase. ${ }^{6}$

Hasil uji klinis telah membuktikan bahwa hiperglikemi merupakan penentu terjadinya 
komplikasi DM kronik. Advanced glycation end products (AGEs) adalah biokimia abnormal yang terdapat pada DM seperti pada radang seluruh tubuh. Mekanisme yang mendasari multifaktor, akan tetapi peran utamanya diperantarai oleh jalur diacylglycerol (DAG)-protein kinase $\mathrm{C}$ (PKC). PKC mempunyai banyak efek yang merugikan pada pembuluh darah meliputi aktivasi produksi enzim superoksid seperti : niotinamide adenine dinucleotide phosphate (NADPH) oksidase, uncoupled endothelial nitric oxide synthase (NOS III). Superoksid yang diproduksi melalui perantara PKC dapat menginaktivasi NO produksi endothelium dan dapat menghambat aktivitas maupun ekpresi target NO pada soluble Guanilat siklase. Efek dari AGEs pada homeostasis pembuluh darah bersifat progresif dan dapat menjelaskan terjadinya atherosklerosis pada DM. Hiperglikemi dan oksidatif stress memacu pembentukan AGEs pada DM. Di dalam dinding pembuluh darah, AGEs yang berikatan dengan kolagen mungkin sebagai perangkap protein plasma, aktivitas NO dan interaksi dengan reseptor spesifik untuk memodulasi sejumlah besar sifat seluler. AGEs menginisiasi reaksi oksidatif yang memacu pembentukan low density lipoprotein (LDL) teroksidasi. Interaksi antara AGEs dengan endothelium terakumulasi dalam plak atherosklerosis, Interasi antara AGEs dan komponen dinding pembuluh darah dapat meningkatkan permeabilitas vaskuler ekpresi dari aktivitas prokoagulan dan pembentukan reactive oxygen species yang menghasilkan peningkatan leukosit endothel molekul addhesi. Pada hiperglikemi akut telah diketahui terjadi peningkatan kadar $\mathrm{NO}, \mathrm{Cu}-\mathrm{Zn}$ Superokside dismutase ( $\mathrm{Cu}-\mathrm{Zn}$ SOD) dan penurunan kadar thiobarbituric acid -reactive substances (TBARS) dalam plasma. $^{6}$

\begin{tabular}{lllr}
\multicolumn{2}{c}{ Endothel DM } & terjadi \\
peningkatan produksi O2 dan
\end{tabular} $\mathrm{H} 2 \mathrm{O} 2$, selanjutnya terjadi peningkatan produksi $\mathrm{OH}$ intraselluler. $\mathrm{OH}$ inilah yang menginduksi terjadinya disfungsi endothelium diabetic. Reaktive oxygen spesies (ROS) diproduksi di lokasi trauma dan radang. Kadar rendah dari ROS berfungsi sebagai molekul signaling intermediate dalam regulasi aktivitas penting dari sel seperti sel pertumbuhan (cell growth) dan sel respon adaptasi (cell adaptation responses). ROS dalam konsentrasi tinggi dapat menyebabkan trauma dan kematian dari sel. Endothel pembuluh darah merupakan target utama dari oksidatif stress. Oksidatif stress meningkatkan permeabilitas endothel vaskuler, kemudian memacu adhesi lekosit, selanjutnya mempengaruhi sinyal tranduksi reaksi redoks sebagai regulator faktor transkripsi dalam endothelium. Hiperglikemi dapat mempengaruhi perubahan proses redoks intrasel yang menghasilkan penurunan NADPH sel. Akumulasi dari AGEs yang terbentuknya berhubungan 
erat dengan stress oksidatif dan hasil dari disfungsi endothel mungkin merupakan awal perjalanan diabetes tipe I. Berkurangnya kapasitas NOS untuk memproduksi NO secara ekperimen telah dibuktikan pada endothel dipapar pada lingkungan diabetes. Ekpresi yang berlebihan dari growth factor juga terjadi pada diabetes dan berhubungan erat antara proliferasi sel endothelium dan otot polos pembuluh darah yang memungkinkan terjadi neovasularisasi. Pada diabetes cenderung terjadi peningkatan stress oksidatif dan terjadi peningkatan oksidasi lipoprotein khususnya low density lipoprotein (LDL-C). Tingginya kadar asam lemak dan hiperglikemi menginduksi dan meningkatkan kadar oksidasi pospolipid seperti halnya protein. DM pada manusia berhubungan dengan kecenderungan protrombotik maupun peningkatan agregasi platelet, lebih lanjut TNF melibatkan hubungan antara diabetes resisten insulin dan disfungsi endothel. Sedangkan disfungsi endothelium berhubungan erat dengan terjadinya mikroangiopati dan atherosclerosis pada DM. ${ }^{6}$

\section{Pengaruh Diabetes Mellitus Gestasional Terhadap Aliran Darah Uteroplasenta}

Aliran darah uteroplasenta (uteroplasental blood flow /UPBF) yang normal sangat penting untuk perkembangan dan pemeliharaan janin yang sehat. Dalam keadaan hamil, pembuluh darah ke uterus mengalami maksimal dilatasi. ${ }^{4,7} \mathrm{DM}$ berhubungan dengan peningkatan penyakit kardiovaskuler, penemuan klinik dan eksperimental telah membuktikan bahwa DM dan resistensi insulin dapat menyebabkan disfungsi endothel. ${ }^{6}$ Manifestasi klinik dari GDM dikaitkan dengan kondisi hiperglikemi, hiperlipidemi, hiperinsulinemi dan disfungsi endothel fetoplasenta. Beberapa organ menunjukkan perubahan struktur dan fungsional termasuk disfungsi endothel makro maupun mikrosirkulasi dalam sirkulasi fetoplasenta. ${ }^{18}$

Peran endothel dalam mengatur tonus pembuluh darah sangat tergantung pada produksi endothelialderived relaxing factor (EDRF) dan endothelial-derivedcontracting factors $(E D C F)$. Dalam keadaaan normal terdapat keseimbangan antara produksi endothelial-derived relaxing factor dan endothelial-derived contracting factors sehingga terdapat keseimbangan antara kontraksi dan relaksasi dari pembuluh darah 2,5 . Endothel yang mengalami disfungsi akan berakibat vasokontriktor tidak ada yang menetralisasi sehingga tonus arteria meningkat. Kondisi disfungsi endothelium ini akan menyebabkan peningkatan produksi endothelin-1 dan endothelium-derivedvasocontrictor yang lain yang selanjutnya akan mempengaruhi vasospasme dan peningkatan kekakuan arteri. $^{5,6}$

Pembuluh darah arteri myometrium merupakan pembuluh darah yang penting untuk menyalurkan darah dari sirkulasi maternal untuk pertumbuhan janin. Arteri myometrium mempengaruhi aliran darah ke fetus, gangguan tonus dari arteri myometrium akan menyebabkan gangguan aliran darah untuk pertumbuhan fetus. Telah diketahui bahwa kekuatan aliran darah berbanding dengan $4 \mathrm{x}$ diameter 
pembuluh darahnya, jika terjadi perubahan kaliber lumen pembuluh darah arteri walaupun kecil, maka akan menyebabkan perubahan yang bermakna terhadap aliran darah ke fetus. ${ }^{18}$

Diabetes Mellitus Gestasional, sintesis dan bioavailabilitas NO mengalami perubahan yang selanjutnya menyebabkan perubahan aliran darah ke plasenta dan berakibat pertumbuhan dan perkembangan janin terbatas. Pembuluh darah plasenta dan segmen distal dari tali pusat (umbilical cord), merupakan pembuluh darah tanpa inervasi oleh karena itu, tonus pembuluh darah tersebut sangat tergantung pada vasokonstriktor dan vasodilator yang disintesa dan dilepas oleh endothel. ${ }^{17}$ Penurunan kemampuan endothel pada pasien Diabetes Mellitus Gestasional untuk memproduksi dan melepaskan $\mathrm{NO}$ tersebut menyebabkan gangguan vasodilatasi pembuluh darah ke plasenta maupun umbilikus yang selanjutnya aliran darah ke janin juga menurun $^{3}$.

Ibu GDM terjadi penurunan endothelium dependent relaxation dari pembuluh darah myometrium dibandingkan dengan pembuluh darah myometrium pada ibu hamil normal. ${ }^{17}$ Penurunan sintesa NO juga terjadi pada pembuluh darah plasenta ibu hamil dengan DM yang menyebabkan peningkatan resistensi vaskular. Otot polos pembuluh darah pasien diabetes mellitus juga mengalami penurunan kepekaan efek vasodilatasi dari NO. Dengan demikian pada GDM besar kemungkinan terjadi penurunan aliran uteroplasenta karena terjadi disfungsi endothel vaskuler yang berakibat vasokontriktor tidak ada yang menetralisasi sehingga tonus arteria meningkat.

\section{Intervensi pada Gestational Diabetes Mellitus (GDM)}

Tatalaksana GDM secara umum adalah dengan pengaturan diet, latihan fisik selama tidak ada kontraindikasi, pengawasan dan kontrol gula darah, dan terapi farmakologi. ${ }^{20}$ Dalam tulisan ini Penulis akan lebih banyak membahas tatalaksana farmakologis pada GDM.

\section{Terapi Farmakologi pada GDM}

1. Terapi Insulin

American College of

Obstetricians and Gynecologist (ACOG) menyarankan bahwa insulin sebaiknya diberikan untuk menurunkan risiko makrosomia dengan kadar glukosa puasa $>95 \mathrm{mg} \%$ atau kadar glukosa 1 jam postprandial > 130-140 $\mathrm{mg} \%$ atau kadar gula 2 jam postprandial > $120 \mathrm{mg} \%$. Sampai dengan saat ini belum ada penelitian random klinis luas yang menentukan cut-off point untuk pemberian insulin. Terdapat 3 penelitian random klinis yang menyarankan dimulainya terapi insulin tanpa melihat kadar glukosa ibu bila hasil lingkar perut abdomen fetus melebihi 75 percentil melalui pemeriksaan USG. ${ }^{20}$

Pada kasus kadar gula darah tidak dapat terkontrol maka terapi insulin sebaiknya aktif dimulai. Meskipun beberapa penelitian random klinis menunjukkan bahwa obat antidiabetik oral glyburide tidak mempengaruhi fetus, keamanan obat glyburide ini belum terbukti dan terapi sebaiknya diganti ke terapi insulin. Dalam terapi insulin harus selalu diingat bahwa untuk tujuan kontrol ketat gula darah maka kadar insulin harus dipertahankan sesuai pola sekresi fisiologisnya. Terapi insulin intensif tersebut dapat menggunakan insulin 
jangka kerja menengah atau pendek (rapid) atau sangat pendek (ultrarapid). ${ }^{21}$

\section{Obat Antidiabetik Oral}

Beberapa penulis terakhir melalui penelitian sistematik pada obat antidiabetik oral untuk terapi GDM menunjukkan tidak ada perbedaan bermakna pada outcome kehamilan ketika dibandingkan penggunaan insulin dan 6 penelitian acak yang melibatkan 1.338 ibu hamil. Tidak didapatkan peningkatan risiko neonatal hipoglikemia, makrosomia atau risiko section caesaria, dan kadar gula darah maternal. Penelitian tentang glibenklamid untuk terapi GDM tetap dilanjutkan dan meskipun consensus ADA dan ACOG meromendasikan tidak menggunakan glibenklamid untuk GDM, Glibenklamid tampak masih cukup efektif dan aman dalam evidensi. Glibenklamid juga lebih murah dibandingkan insulin. ${ }^{20}$

Hasil penelitian 3 metaanalysis menunjukkan bahwa pada jangka pendek metformin lebih baik dari segi outcome maternal (peningkatan berat badan dan hipertensi yang diinduksi oleh kehamilan) namun tidak demikian dengan outcome fetus (lebih banyak kelahiran prematur dan lebih sedikit hipoglikemia neonatal). Perlu diingat bahwa metformin berhubungan dengan kegagalan terapi yang tinggi dan keamanan penggunaan jangka panjangnya belum diketahui. Pada jangka pendek, glibenklamid lebih inferior dibandingkan dengan insulin metformin sedangkan metformin (bersama dengan insulin bila diperlukan) sedikit lebih baik dibandingkan insulin. Berdasar penelitian tersebut glibenklamid sebaiknya tidak digunakan untuk terapi pasien dengan GDM bila tersedia metformin atau insulin. ${ }^{13,22,23}$
Metformin diketahui memperbaiki sensitivitas terhadap terapi insulin. Metformin juga mempunyai efek langsung apda proteksi sel-sel endothel. Metformin dilaporkan dapat menurunkan adhesi monosit pada sel endothelia manusia. Lebih jauh beberapa penelitian menunjukkan bahwa terapi metformin memperbaiki reaktivitas vascular. Terapi metformin selama 3 bulan menunjukkan peningkatan vasodilatasi endothel yang bergantung pada asetilkolin, namun tidak menunjukkan peningkatan vasodilatasi endothel yang bergantung pada nitroprusside pada pasien DM type $2 .^{13}$

3. Terapi Disfungsi Endothel pada Diabetes

Endothelium merupakan "gateway "/pintu masuk menuju penyakit vascular, sehingga terapiterapi yang diketahui untuk menurunkan risiko kardiovskular akan memperbaiki fungsi endothel. Menurunnya kadar kolesterol berhubungan dengan menurunnya kejadian kardiovaskular dan berbagai penelitian mengindikasikan bahwa efek ini disertai dengan membaiknya fungsi endothel. Angiotensin-converting enzyme inhibitor juga mengurangi risiko kardiovaskular dan memperbaiki fungsi endothel. Pasien dengan DM type 2 mempunyai fungsi endothel yang abnormal yang dapat diperbaiki dengan metformin, obat yang mengurangi risiko infark pada pasien overweight. Beberapa obat farmakologi diduga mempunyai perlindungan terhadap vascular melalui mekanisme selain efek terapi primernya. ${ }^{13}$

A. Obat-obat penurun Lemak Statin. Obat-obat yang diketahui menurunkan kolesterol, menunjukkan efek protektif vascular setidaknya melalui aktivasi 
AMPK. Berberin mempunyai efek yang berbeda dengan golongan statin dalam hal berberine meningkatkan ekspresi LDL melalui mekanisme posttranskripsional yang menstabilkan membrane mRNA. Berbagai bukti menunjukkan bahwa berberin mempunyai efek menguntungkan pada penyakit kardiovaskular misalkan dengan supresi respon proinflamasi makrofag, perbaikan metabolism glukosa melalui induksi glikolisis, dan pencegahan kerusakan endothel yang diinduksi hiperglisemia, dan penguatan efek vasodilatasi AMPK. ${ }^{13}$

\section{B. Antioksidan}

Dengan dasar pada pengertian akan patofisiologi terjadinya oksidatif stress, strategi pencegahan pembentukan radikal oksigen reaktif mendukung penggunaan antioksidan pada terapi cardiovascular pasien diabetes. Antioksidan seperti vitamin E atau C membutuhkan konsentrasi yang sangat besar berkompetensi dengan ONOOpada target endogen. Beberapa penelitian berikutnya menunjukkan suplemen vitamin E tampaknya menurunkan kejadian kardiovakular pada pasien DM dan genotype Hp 2-2 (haptoglobin, sebuah protein antioksidan mayor). Dalam dekade terakhir beberapa kelas katalisir dekomposisi $\mathrm{ONOO}^{-}$(misalkan ebselen dan komponen metalloporphyrine FP15, FeTPPS dan FeTMPS) diuji pada berbagai penelitian dewan coba. Hasil penelitian-penelitian tersebut menyimpulkan bahwa neutralisasi $\mathrm{ONOO}^{-}$bermakna menunda pembentukan disfungsi endothel, kardiomiopathy, retinopathy, nephropathy, dan neuropathy pada DM. $^{13}$

\section{Thiazolidinediones}

Terapi thiazolidinediones menunjukkan perbaikan vasodilatasi endothel pada pasien DM dan pada pasien dengan sindroma metabolik tanpa DM. Thiazolidinediones menunjukkan manfaat vascular tidak bergantung pada efeknya terhadap sensitivitas insulin dan terhadap inflamasi. ${ }^{13}$

\section{AMPK}

Efek farmakologi metformin berhubungan dengan aktivasi AMPK. Berbagai efek bermanfaat dari beberapa terapi seperti latihan fisik, statin, thiazolidinediones, leptin, adiponcetin, rosiglitazone dimediasi minimal sebagian oleh aktivasi AMPK pada sel endothel. Aktivasi AMPK secara tidak langsung dapat memperbaiki fungsi endothel vascular melalui perbaikan pada sensitivitas insulin dan perbaikan profil metabolism. Dugaan ini diperkuat dengan temuan bahwa AMPK berperan penting pada homeostasis endothel dengan meningkatkan bioaktivitas NO dan biogensis mitokondria serta menekan inflamasi dan produksi ROS/ ONOO pada sel endothel. ${ }^{13}$

\section{E. Kontrol Sitokin}

Para peneliti masih mencari sebab kondisi pro-inflamasi pada GDM. Ada kemungkinan bahwa selama resisten insulin, peningkatan IL-6 tidak hanya menurunkan sensitivitas insulin namun juga menekan tranduksi sinyal insulin sehingga bergabung dengan efek antiinflamasi insulin, dengan demikian meningkatkan inflamasi selama resistensi insulin. ${ }^{24}$

Insulin ditemukan mempunyai efek non -metabolik yang menyerupai antiinflamasi. Insulin telah terbukti menekan beberapa faktor transkripsi pro-inflamasi, misalkan faktor nuclear (NF- $\kappa \beta$ ), Egr-1 (early growth response protein 1) dan mengaktifkan protein-1 
(AP-1) dan gen-gen yang memediasi inflamasi. ${ }^{24}$

Sitokin proinflamasi berperan sangat penting pada fungsi plasenta dalam kehamilan. Peningkatan resistensi insulin pada kehamilan sebagian dipengaruhi oleh sitokin plasenta seperti TNF- $\alpha$ dan leptin. Penelitian pada ekspresi gen-gen inflamasi pada GDM menunjukkan perubahan pada ekspresi gen plasental. ${ }^{24}$

F. NO dan Asymmetric Dimethylarginine (ADMA)

Transport nutrisi plasenta bergantung pada perkembangan vascular yang menentukan aliran darah ke plasenta. NO meregulasi aliran darah plasenta. ADMA berhubungan dengan gangguan aliran arteri uterina. Beberapa evidensi penelitian membuktikan peranan NO dan ADMA pada kehamilan normal dan insufiensi plasenta. Dengan berkembangnya pengetahuan akan mekanisme gangguan jalur ADMA$\mathrm{NO}$, pilihan tambahan untuk intervensi terapetik akan dapat ditemukan. ${ }^{24}$

Berbagai penelitian terus berusaha menemukan terapi-terapi baru untuk memperbaiki endothel dan sirkulasi uteroplasenta pada pasien GDM. Setiap saat dan di masa depan akan selalu ditemukan faktor, hormone, adipositokin, dan sebagainya yang baru yang mana terlibat dalam terjadinya resistensi insulin pada GDM. Namun belum diketahui pasti bagaimana ibu hamil tidak mampu memelihara keseimbangan insulin dan mengalami GDM. Bagaimanapun berbagai penelitian telah mencoba menjelaskan hal tersebut misalkan penelitian tentang faktor genetic, penelitian subseluler, autoimunitas, faktor diet dan lingkungan, dan sebagainya. ${ }^{25}$

\section{SIMPULAN}

Diabetes mellitus pada kehamilan (Gestational Diabetes Mellitus /GDM) adalah intoleransi glukosa yang ditemukan pertama kali pada masa kehamilan dan sering menimbulkan komplikasi pada ibu yang mengandung, maupun janin yang dikandung. Beberapa organ pada GDM mengalami perubahan struktur dan perubahan fungsi termasuk disfungsi endothel mikro dan makro sirkulasi fetoplasenta.

Endothelium-derived relaxing faktor khususnya prostasiklin dan nitrik oksid merupakan hal yang penting dalam mengontrol sirkulasi fetoplasental. Endothel vaskuler pasien GDM mengalami disfungsi, sehingga sintesa dan pelepasan prostasiklin dan nitrik oksid (NO) mengalami gangguan yang selanjutnya tonus arteria meningkat. Peningkatan tonus arteri yang menuju uterus akan menurunkan aliran darah uteroplasenta dan akhirnya menurunkan umbilical blood flow (UmBF). Beberapa evidensi penelitian membuktikan peranan NO dan ADMA pada kehamilan normal dan insufiensi plasenta. Dengan berkembangnya pengetahuan akan mekanisme gangguan jalur ADMA-NO, pilihan tambahan untuk intervensi terapetik akan dapat ditemukan. Berbagai penelitian lain terus berusaha menemukan terapi-terapi baru untuk memperbaiki endothel dan sirkulasi uteroplasenta pada pasien GDM.

\section{DAFTAR PUSTAKA}

1. American Diabetes Association. Diagnosis And Classification Of Diabetes Mellitus. Diabetes Care. 2012 Jan. Volume 35, Supplement 1

2. US. Preventive Services Task Force (USPSTF). Screening for Gestational Diabetes Mellitus. AHRQ Publication. 2014. No. 13- 
05191-EF-2.

http://

www.uspreventive

servicestaskforce.org/uspstf13/gdm/ gdmfinalrs.htm

3. Leiva A. Pardo F. Ram'irez M. Far'ias M. Casanello P. and Sobrevia L. Fetoplacental Vascular Endothelial Dysfunctionas an Early Phenomenonin the Programming of Human Adult Diseases in Subjects Born from Gestational Diabetes Mellitus or Obesity in Pregnancy. Hindawi Publishing Corporation Experimental Diabetes Research Volume 2011, Article ID 349286, 18 pages

4. Ngan Kee. Uteroplacental Blood Flow. In:Chestnut's Obstetric Anesthesia Principle and Practice $5^{\text {th }}$ ed. Saunders an imprint of Elsevier Inc. 2014:39-54.

5. Tabit CE. Endothelial dysfunction in diabetes mellitus: Molecular mechanisms and clinical implications. Rev Endocr Metab Disord. 2010 March ; 11(1): 61-74.

6. Hadi HAR dan Suwaidi HJ. Endothelial dysfunction in diabetes mellitus. Vascular Health and Risk Management. 2007:3(6) 853-876.

7. Frolich MA. Maternal \& Fetal Physiology and Anesthesia. In: Morgan \& Mikhail's Clinical Anesthesiology $5^{\text {th }}$ ed. New York : McGraw Hill, 2013:825-841.

8. Murray MJ et al. Maternal Physiologic Changes in Pregnancy. Faust Anesthesiology Review. $4^{\text {th }}$ edition. 2015. Elsevier.

9. Yessoufou A and Moutairou K . Maternal Diabetes in Pregnancy: Early and Long-Term Outcomes on the Offspring and the Concept of "Metabolic Memory. Experimental Diabetes Research Volume 2011, Article ID 218598, 12 pages doi:10.1155/2011/218598

10. Lovati E, Baneventi F, Simonetta , Laneri M. Gestational diabetes mellitus: Including serum pregnancy - associated plasma protein-A testing in the clinical management of primiparous women? A case-control study. Diabetes Research and Clinical Practice, Elsevier Ireland Ltd. 2013. Volume 100, Issue 3, Pages 340-347.

11. Mursi C, Marwoto. Aliran Darah Uteroplasenta. Dalam: Anestesi Obstetri. Editor Bisri T, Wahjoeningsih S, Suwando BS. Komisi Pendidikan Spesialis Anestesiologi Konsultan Anestesi Obstetri KATI, 2013

12. Leopold JA. The Endothelium. Vascular Medicine A companion to Braunwalld's diseases $2^{\text {nd }}$ Edition. 2013. Saunders an inprint of Elsevier Inc.

13. $\mathrm{Xu} \mathrm{J}$, and Zou MH. Molecular Insights and Therapeutic Targets for Diabetic Endothelial Dysfunction. Circulation. 1 September 2010; 120 (13): 1266-1286. doi:10.1161 CIRCULATIONAHA.108.835223

14. Cines DB, Pollak ES, Buck CA, Loscalzo J, Zimmerman, McEver RP, et al. Blood, Endothelial Cells in Physiology and in Pathophysiology of Vascular Disorder. J Am Soc Hematol 1998; 9: 3527-3561.

15. Holvoet P, Collen D. Thrombosis and Atherosclerosis. Curr Opin Lipidol 1997; 8: 320- 328

16. Pepine CJ, Drexter H, Dzau VJ. Endothelial Cell in Cardiovascular Health and Disease. Florida: University of Florida, 1996.

17. Shireman PK, Pearce WH. Endothelial Cell Function: Biologic and Physiologic Functions In Health And Disease. AJR Am J Roentgenol 1996; 166: 7-13.

18. Chirayath $\mathrm{HH}$, Wareing $\mathrm{M}$, Taggart MJ and Baker BN. Endhothelial Dysfuction in Myometrial Arteries of Women with Gestational Diabetes. Diabetes Research and Clinical Practice. 2010. 89:134-140.

19. Correti MC, Panjrath GS, Jones SR. Endothelial Function and Dysfunction.

Preventive 
Cardiology Companion to Braunwalds Heart Diseases. 2011.Saunders an imprint Elsevier Inc.

20. Amorim MMR, and Katz L. Gestational Diabetes; EvidenceBased Screening, Diagnosis and Treatment. 2012. Viewed 6 Februari 2015. http// www.Intechopen.com

21. Sugiyama T. Management of Gestational Diabetes Mellitus. 2011. JMAJ 54 (5): 293-300, 2011.

22. Rojas LB, and Gomes MB. Metformin: an old but still the best treatment for type 2 diabetes. Rojas and Gomes Diabetology \& Metabolic Syndrome 2013, 5:6 http://www.dmsjournal.com/ content $/ 5 / 1 / 6$

23. BMJ. Glibenclamide, metformin, and insulin for the treatment of
Gestational Diabetes: a systematic review and meta-analysis. 2015. http//doi.org/10.1136/bmj.h102

24. Mrizak et al. Inflammation And Impaired Endothelium Dependent Vasodilatation In Obese Women With Gestational Diabetes Mellitus: Preeliminary Results. 2013. Lipids in Health and Disease. http://www lipidworld.com/content/12/1/93

25. Al-Noaemi MC, and Shalayel MH. Pathophysiology of Gestational Diabetes Mellitus: The Past, the Present and the Future, Gestational Diabetes. InTech. http://www.intechopen.com/books/ gestationaldiabetes/ pathophysiology-of-gestationaldiabetes-mellitus-the-past-thepresent-and-the-future 